\title{
プラトン哲学におけるソーマの原理的特性
}

木庭 康樹

\section{The fundamental characters of soma in Plato's philosophy}

\author{
Kohki Kiniwa
}

\begin{abstract}
An attempt was made to clarify Plato's view of soma by considering the fundamental characteristics of soma in Plato's philosophy. The concept of soma had extensive ramifications in classical Greek, denoting not only the human body but also the elemental bodies (fire, water, air, earth), the corpse, the cosmic body, the celestial body, the animal body and so on, and Plato's view of the human body also included many background factors. According to Laws, one of Plato's later works, soma had three common characteristics: spaciality, movability and sensibility, and it took on an aspect different from the present-day concept of the body. Firstly, the spaciality of soma is the likeness of Form, which is copied into chora (the place of plenum), and it is a solid, which is geometrically formed by following Form. Secondly, the movability of soma is originally motion by others or disorderly and dotted linear motion, which is necessarily caused by accidental collision between particles; however, in connection with Soul and Reason, it becomes autonomical and orderly circular motion. Thirdly, the sensibility of soma is pathema (accidental affection), which is based on multiplicity in the geometrical structures of particles. Pathema injures Soul and soma when it is left to Chance and Ignorance, but in the control of Reason it contributes to the realization of good and the restoration of order. Since soma, which has close connections to Soul, Reason and Form, is represented as such a subordinate and necessarily conditional existence in Plato's philosophy, the human body, which is also called soma, should be considered on the basis of the above-mentioned fundamental characteristics.
\end{abstract}

\section{Key words : Laws, solid, motion by others, pathema}

(Japan J. Phys. Educ. Hlth. Sport Sci. 48: 555-572, September, 2003)

筑波大学体育科学系

テ 305-8574 茨城県つくば市天王台 1-1-1

連絡先 木庭康樹
University of Tsukuba, Institute of Health and Sport Sciences

1-1-1 Tennohdai, Tsukuba, Ibaraki 305-8574

Correspondingauthorkohki@taiiku.tsukuba.ac.jp 
キーワード：『法律』, 立体, 他動, パテーマ

\section{はじめに}

プラトンは『クラテュロス』や『ゴルギアス』 において「身体は墓である $\sigma \omega \hat{\mu} \mu \alpha \tilde{\eta} \mu \alpha 」$ とし， 人間にとって本来の生とは, 死後, 心魂が身体か ら解放されることにあるとしている声1)。つまり 不死なる心魂は，生成消滅する身体からは独立し た神的な実体であるが，反対に様々な情念や欲望 を惹き起す人間の身体は，いわば心魂にとっての 牢獄なのである.このようなプラトンの身体に対 する否定的評価は，後の西洋思想に決定的な影響 力を持つことになったのであり, さらにはギュム ナスティケー論注 2) にとっても文字通り手枷足枷 となってきたように思われる。

たとえば，これまでなされてきたZeller（1889） やVlastos (1939), Brochard（1912）などの研 究は, あくまで物体論が中心であるし, さらにこ れらの知見をふまえた上で身体論が展開されるこ とも，ほとんどなかったと言ってよいだろう。と くにプラトン研究ではCherniss（1954）の論文 に代表されるように，人間の身体は悪の問題とと もに論じられ，何らかの負荷価值を付与されてい ることが多いのである.

しかしながら，近年，プラトン研究にあっては， かれの身体論を再評価し，人間の身体を考察の対 象とするものも，若干ではあるが，見られるよう になってきている注3). 同じく筆者も，別の機会 において，上のようなプラトンの価值階層論を維 持しながら，かれの身体論を明らかにする方法に ついて述べており，それと同時にプラトンのギュ ムナスティケー論にも一つの方向性を見定めつつ あると言える注4!

とくに，プラトンの場合「ソーマ $\sigma \hat{\omega} \mu \alpha 」 と い$ う語は,ほとんどすべての著作において言及され， 人間の身体のみならず，生命の失われた死体や動 物のからだ，天球や天体，さらにはそれらを構成 する単純物体（元素）までをも含む非常に大きな 外延をもっている望5)。またこれらの対象がすべ てソーマと言われるのである以上，プラトン自身
にも何かそれらに共通する観念が存在していたは ずである。

しかし，現代においては，ソーマと等しい外延 を持つような語は存在せず，プラトンの言う身体 (ソーマ）も，ごく限られた意味においてしか理 解されないように思われる.というのも現代の自 然科学的な世界像における, 無機質で, 無目的で, 没価值的な物質の捉え方は，等質的な空間におけ る物の局在化や実体化，さらには物それ自体にお ける変化や知覚像の成立を前提としており，われ われ現代人の身体観も，このようなデカルト主義 的もしくは唯物論的な考え方の強い影響下にある と考えられるからである。

そこで，本研究の目的は，あらゆるソーマに共 通する原理的な特性を明らかにし，現代の側から ではなく，プラトンの側から身体論を語りうる地 平を切り拓くことにあると言える。おそらく，こ のような地平は, 各種ソーマの綜合的な把握をも たらすとともに，現代において硬直した身体観を 柔軟にし，拡張することになるような可能性を内 在させていると考えられる，またソーマの原理的 特性を把握することで，あらゆるソーマの成立原 因が明らかにされ，さらには同じ原理的規定のも とにある人間の身体に，ギュムナスティケーが関 わり得る根拠を見出すということも可能となって くるだろう。

なお，考察の手順としては，まず，プラトンの 最晚年の著作である『法律』からソーマの用例を いくつか取り上げ（I．『法律』におけるソーマ), つぎに,それらに共通する原理的特性をそれぞれ， 主にプラトンの後期作品を通して分析していくこ とにする（II．ソーマの空間性， III．ソーマの運 動性, IV.ソーマの感覚性)。というのも『法律』 は全十二巻の大著であり，このプラトンの最終作 品にはかれが最晚年において到達した哲学理論の すべてが㠜縮されているのであって，我が国にお けるプラトン研究の大家である田中美知太郎も， 『法律』を終点からの出発として, プラトン哲学 の基準におく方法論を展開しているからである (田中，1981，pp.8-11).またこの『法律』には, 立体や感覚媒体といった特殊なものを除き，ソー 
マの用例がほとんどすべての種類にわたって見ら れることから，田中のように『法律』を出発点と することは，ソーマ論を展開する上でも十分に方 法論的な意義を持つと考えられる.

\section{I『法律』におけるソーマ}

『法律』という作品自体は，クレタ島を舞台に して，アテナイからの客人ら三人が新たに植民地 として建設されるマグネシアという国家のため に，国制や法律についての具体的な草案を行うと いう内容になっているが，そこでは，人間のから だ（ソーマ）についても，幼览の身体育成（ $L g$. VII 788D-789D）や自然環境による人体への影 響 $(L g . V 797 \mathrm{C}-\mathrm{D})$ ，死体の埋葬法 ( $L g . \mathrm{XII}$ 958D-E) など，まさに「摇りかごから墓場まで」 論じられているのである.

とくに，『法律』第十巻では，無神論的な自然 学説への反駁として，心魂の方がすべてのソーマ よりも先にあることが証明され，各種ソーマの類 概念である「もの」としてソーマが，心魂との鋭 い対比によって次のように語られている.

アテナイからの客人では，〔心魂の〕気質，性 格, 意欲, 計算, 真なる判断, 配慮, 記憶とい ったものは,「もの (ソーマ)」の長さ, 幅, 奥 行き, 力よりも先にあったものということにな るでしょう，もしも心魂の方が「もの(ソーマ)」 よりも先にあったとすればですよ。

クレイニアス そうならざるをえません（プラ トン, 1976a，Lg. X 896C-D) $)^{\text {注6) }}$.

つまり，ここからは，心魂に属する様々な精神 作用に比して，ソーマに属する空間的な性質が挙 げられていることがわかる．またこの箇所の少し 後においては，上のような精神作用のすべてが心 瑰の「第一次的な運動」として総括され, 他方, ソーマの運動もそれに付随する感覚的諸性質を含 めて「第二次的な運動」と呼ばれているのである.

アテナイからの客人……では，心魂は，天や地
や海にあるものすべてを，自分自身のもつ運動 によって導いているのですね。つまり，それら の運動には，意欲，考察，配慮，計画，正しい 判断や間違った判断，悦びや苦しみ，大胆や恐 れ，憎しみや愛という名前がつけられているの ですが，そういった運動や，またこれらと同類 のものか，あるいは第一次的な運動であるもの すべてによって，心魂は万物を導いているわけ です。そして，これらの運動は，今度は，「も の (ソーマ)」のもつ第二次的な運動を自分の 支配下において，万物を導きながら，増大や減 少，分離や結合，およびこれらに伴うところの 温かさや泠たさ，重さや軽さ，硬さや軟かさ， 白や黒, 苦さや甘さなどを生じさせるのです. つまり，心魂は，これらの運動変化をすべて用 いるのですが，なおその上に，「知性」の助け をも得るなら……, 万物を正しくまた幸福に導 くことになるし，他方，無知を仲間にした場合 は，万物をそれとは反対の状態にしてしまうわ けです。一どうでしょう，以上述べたことは事 実そのと㧍りであるとわたしたちは考えること にしましょうか，それとも，事実はそれとはち がっているかもしれないと，な擬ってみるこ とにしますか.

クレイニアス いや，その必要は少しもありま せん（プラトン, 1976a, Lg. X 896E-897B)。

このように，増大や減少，分離や結合といった ソーマの運動変化とともに，温かさや冷たさ，重 さや軽さ，硬さや軟かさ，白や黒，苦さや甘さな どの感覚的諸性質が具体的に挙げられており，以 上に挙げた『法律』第十巻の用例からは，「もの」 としてのソーマが, 空間性，運動性，感覚性とい った三っの特性を持つことが読みとれるのであ る注7.またこれらの特性があらゆるソーマに共 通して言えるのであれば，各種のソーマにもそれ らが見出されるはずであろう。

たとえば，同じ『法律』第十巻では，自然界の 生物として語られている天体について，次のよう な説明がなされている. 
太陽のからだ（ソーマ）は，誰でもがこれを目 にしているが，その心魂は，誰ひとりこれを見 ることはできません，そしてこのことは，他の どの生きもののからだ（ソーマ）についても同 じであって，それが生きている間であろうと， 死のうとしているときであろうと，そのものの 心魂は肉眼では見られません。しかし，この心 魂という種族は，からた（ソーマ）のどんな感 覚によってもまったく感覚されないものである けれども，わたしたちにほんらいまといついて いて,「知性」によってはとらえられるもので あると期待してよい理由は，大いにあるのです (プラトン, 1976a, Lg. X 898D-E).

つまり，天体のからだも，ソーマである限り， 感覚されるものなのであって，これは上に指摘し たソーマの感覚性に基づくものなのである.

また，『法律』第二巻にある歌舞の説明では, 人間の身体 (ソーマ) とギュムナスティケーの関 係が，次のように述べられている.

アテナイからの客人 他方, 身体（ソーマ）に 関して，遊びに伴う踊りと言った部分について は, もしその運動が身体（ソーマ）の徳をつち かうところまで及べば，身体（ソーマ）をそこ まで技術によって導くことを，わたしたちはギ ユムナスティケーと呼ぶことにしましょう。

クレイニアス 正当です（プラトン，1976a， Lg. II 673A).

すなわち，ここでは，身体運動としての踊りが， 身体の徳（アレテー）を形成するギュムナスティ ケーという技術的な過程の中に位置づけられてい ることがわかる．またこのほかにも，動物体とと もに生物のからだ（ソーマ）一般に対する運動の 必要性が説かれており（Lg.VII 789B-D), ソー マと運動が密接な関係性を持って述べられている のである.

さらに，芸術の判定者の資質が語られる場面で は, 人工物 (ソーマ) としての作品のできばえが, 次のように空間的な観点から判定されるべきであ
ることが言われている.

アテナイからの客人 では, それらの模写にお いて，模做されている人工物（ソーマ）がそれ ぞれ何であるかをひとが知らないとしたら，ど うなるでしょうか.はたしてその人は，それら の模写のうちで, 正しくつくられているものを 認識できるでしょうか. わたしの言おうとして いることは，たとえばこういうことなのです. その作品は, 人工物 (ソーマ) 諸部分の数や位 置に関し，事実あるだけの数を保っているかど うか, また, しかじかの部分がしかじかの部分 の傍に置かれることによって，その人工物（ソ 一マ）はしかるべき秩序を一さらには色と形を 一獲得しているが, そういう秩序をその作品は 保っているかどうか, それとも, それら諸部分 のすべては，ただ雑然と製作されているのか, といったことの認識なのです，まさか，模做さ れている動物の何であるかをまったく知らずに いながら，以上のことを識別できるとは，思わ れないでしょうね.

クレイニアス むろん，どうして識別できま しょうか (プラトン, 1976a, Lg. II 668D-E).

つまり, 数や形, 配置や秩序などは, 芸術作品 の構成上, 不可欠な要素なのであって, とりわけ これらの幾何学的な性質が美的判断の基準におか れていることは, 空間性だけでなく感覚性にとっ ても重要な意味を持つと考えられる。

このように, 空間性, 運動性, 感覚性は, 自然 物と人工物，さらには生物と無生物の区別を問わ ず,あらゆるソーマに共通して見られるのである. しかしながら以下に見るように，プラトン哲学に おけるこれら三つの特性は，現代におけるそれら とはいくらか様相を異にしているようである. 次 節では，まずソーマの空間性について諸家の見解 を参考にしながら，比較的『法律』と成立年代の 近い著作を見てみることにしよう。 


\section{II ソーマの空間性}

一般に『法律』と同じ後期作品とみなされてい る『ティマイオス』において，プラトンは，現代 のわれわれが「空間」と呼んでいるものを，「ケ ノン (空虚)」,「トポス (ところ)」,「へドラ (座)」, 「コーラー (場)」などの言葉によって表している. ただしプラトンの場合，宇宙の内部にケノン（空 虚）は否定され望8，主にトポスはその上を物が 移動する「場所」のようなものとして語られてい ることから ${ }^{\text {i: 9) }}$ ，上に挙げた前二者は，ソーマの 空間性そのものと直接的には関わりがないように 思われる。

また，このような空虚の否定とともに運動の可 能性を認めるということが，一見矛盾した事態で あることをエレア派のメリッソスが次のように述 べていた，と伝えられている.

いかなる空虚もあらぬ，なぜなら空虚はいかな るものでもあら交からすると，いかなるもの でもあらぬものはまた，あうえないのである。 また，それ［ある方もの］は動くことさえできな い.というのも，それはどこにも退去しえず, むしろ充実しているからである．実際，もしそ れが空虚なものであれば，それは空虚へと退去 していくだろう。ところで，いかなる空虚もあ らぬとすれば，それは，退去のためのいかなる 場も持たないであろう（シンプリキオス，1997， DK. 30. B7. 7).

つまり，ここでメリッソスが言わんとしている のは，一つの空虚も残されていないとすると，充 実している物の不可入性が運動の余地を残さない ということである。

これに対し，プラトンは宇宙の内部にケノン （空虚）の存在を認めないが，ディアケノン（間 隙）の存在を認めて, 物に運動の余地を残してい る注 ${ }^{10)}$ 。またこのような充実した物同士の関係は, プラトンの空間的思考の一面を表しており，さら には後に詳しく見るソーマの運動性や感覚性にも
深く関わっているのである.すなわちブロシャー ル (1929, p. 23, Brochard, 1912, p. 107）が指 摘しているように，プラトンは，「空間を以て質 料を説明したのではなく，逆に質料を以て空間を 説明した」注11)のであり，上に挙げた四つのうち， 残りのコーラー (場) とへドラ (座) が，そのよ うな力動的な空間の役割を担っているのである.

たとえば，『ティマイオス』第二部において， コーラーは常にあるイデアを写し出し，その似像 としての生成物を受け入れる受容体であるとされ (Ti. 49A)，そのほかにも「乳母のごときもの (Ti. 49A，52D)」，「すべてのソーマを受け入れ るもの $(T i .50 \mathrm{~B})\rfloor, 「$ 無形のもの $(T i .51 \mathrm{~A})\rfloor$, 「感覚ではなく，まがいの推理によって捉えられ るもの $(T i .52 \mathrm{~B}) 」 と$ 呼ばれている.

とりわけ，ここで重要なのは，コーラーが, 「すべてのものの印影の刻まれる地の台をなし， 入ってくるものによって動かされたり，さまざま の形を取ったりしているものであって，このよう にして入ってくるもののために，時によっていろ いろと違った外観を呈している」（プラトン， 1975a，Ti. 50C）と言われていることであろう. つまりプラトンの言う空間とは，デカルト主義者 の言う等質的な空間ではなく（Sallis，1995； Rosen, 1995), 内包物の性質によって満たされ, 動かされ，変形させられる充実空間なのである。

さらに，宇宙創造以前にも，コーラーがあらゆ るソーマの最小構成要素である四元素 (火水風土)

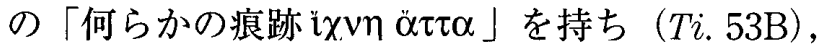
それら四元素のそれぞれもまた「固有の場所

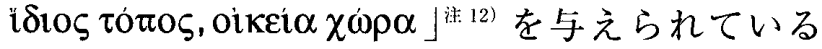
ことからすれば, コーラーは，ある意味において， ソーマから独立した形では存在せず，そこからソ ーマが取り去られても，コーラーだけがそれ自体 として残るような無機質な空間ではないと言える だろう。

ただし，コーラーだけでは，ソーマの空間性に とってまだ不十分である.というのもコーラーは

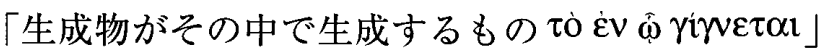
（Ti. 50D）であって，ソーマを内在的に規定する 要素ではないからである.むしろプラトンの場合， 
そのような役割は，イデアの似像としてコーラー

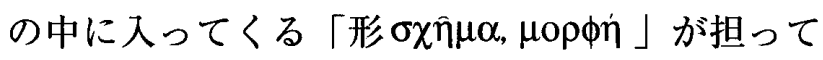
いる．つまりコーラーと似像がそれぞれ，材料と なる「黄金」とそこに作られる「三角形やその他

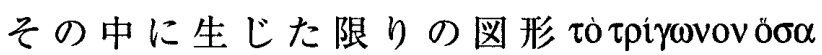

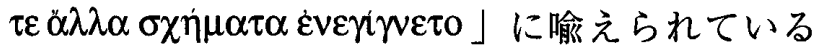
ように（Ti. 50A-B），コーラーを立体化し空間 化するのは，イデアの似像として写し出される幾 何学的対象なのである.

また，同じ後期作品の『ピレボス』では，常に 運動して止まない「無限」の類に，数量間の比例 関係である「限度」の類を混ぜ合わせると，ある 種の生成物が出てくるとされ，この生成した「混 合」の類には，「美」や「強さ」「健康」といった 身体の德（アレテー）が具体例として挙げられて いる.そしてその生成過程については，「一定量

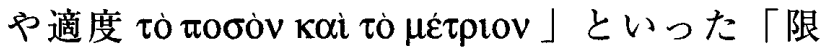
度」が,「無限」の占めているへドラ（座）に入 り込むことで，「無限」がコーラーから流れ去る ことが言われており（Phlb. 24C-D），『ピレボス』 の「限度」と『ティマイオス』の似像は，コーラ 一論を介して結びっくように思われる.

一方，『ティマイオス』では，各種のソーマが 幾何学的な観点から説明され主 ${ }^{13)}$, 幾何学的対象 は，イデア界と現象界とを結ぶ媒介項となってい るのである．また先に見た『法律』第十巻 $(L g . \mathrm{X}$ 896C-D）では，ソーマの性質として「奥行き

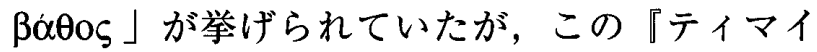
オス』でも，天球が「奥行き」を持った「立体

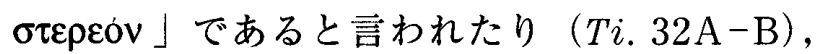
ソーマが「立体」と互換的に使用されたりしてい る（Ti. 55A).すなわちプラトンのテクストにあ っては，点や線，面といった「奥行き」を持たな いものをソーマと呼ぶ用例は存在せず，形や数も 三次元の「立体」となって始めてソーマと呼ばれ るのである。

他方, 『ピレボス』では,「限度」の類が,「等 と二倍と，そしておよそ相互に相反するものの不 一致を終息させ，数の導入によって，これらを度 に合うもの（共通の単位で計ることのできるも の), 調子の合うものにするものの類」(プラトン,
1975b，Phlb. 25D-E）と言われていることから， 『ピレボス』は『ティマイオス』の幾何学的な世 界像に比べ，代数学的な世界像を基調としている ことがわかる．またSayre（1998）によって，代 数学的な対話篇である『ピレボス』は, 幾何学的 な対話篇である『ティマイオス』の発展型として 見なされており，ここからは幾何学に対する代数 学の優位性を窥い知ることができるだろう。

たとえば，同じく最後期の作品と見なされてい る『エピノミス』注 ${ }^{14)}$ では, 共約不可能な数と数 を面積 (平面) や体積（立体）に関係づけ，両者 を比較可能なものに変換することで, 幾何学が数 論に還元されている注15). そしてここでは，数が イデアよりも根本的な存在と見られていることか ら，『エピノミス』の数論は，アリストテレス (1959, p. 46-49, Metaph. 987a9-988a17) が伝 えている「イデア数の説」にもつながる考え方で あるように思われる。つまり「イデア数の説」と は，プラトンがイデアそのものを「一」と「不定 の二 (大と小と)」に分析し，「一」が「不定の二」 を限定して一定のものたらしめるとする説のこと であるが，これら「一」と「不定の二」は，上で 見た『ピレボス』の「限度」と「無限」に近いも のと考苀られているのである（Jackson，1882）。

ただし，ここで重要なのは，このような「一」 や「不定の二」といった数が，イデアの構成要素 であり，さらにそれらがあらゆる存在の構成要素 となっていることである。すなわちこのことと 『エピノミス』の数論を併せて考えるならば，ソ 一マの形相的原理は窮極的には数であり，「一」 であることになるだろう。

このように，『法律」と同じ後期作品とみなさ れる『ティマイオス』や『ピレボス』,『エピノミ ス』には，代数学や幾何学の観点から世界のあり 方を説明するという共通した立場がとられてい る。つまり，「少なくとも物体的なものにおいて は，イデアの模像は図形と数量関係（ことに比） によって成立するということである，この自然界 においては，イデアの合理性ないし論理性は，空 間化され，感覚界に投影されて幾何学的な図形と 数関係という空間的合理性ないし論理性になるの 
である」(鈴木，1982，p. 257）注16)。したがって， このような感覚的事物に内在する立体性こそが, まさしくソーマの空間性なのであり，また言い換 えるなら，それは充実空間であるコーラーと常に あるイデアとの間に成立する似像に他ならないの である。

\section{III ソーマの運動性}

さて，上で見たように，充実空間においてソー マが互いに接触し，立体的な構造に即した運動変 化を㧍こなっているとすると，その運動性はいか なる様相を呈するのだろうか，ここでは，まずこ の充実空間ということを念頭において，もう一度 『法律』第十巻の連動論を見てみることにしよう。

『法律』第十巻では，無神論的な自然学説への 反駁として，心魂の方があらゆるソーマよりも先 なる存在であることが, 十種類の運動（1)回転運 動, (2)移動, (3)分解, (4)合成, (5)増大, (6)減少, (7)消滅，8生成，(9)他動，(10)自動）の分析から証 明され，なかでもプラトンは，(10の自動と(9)の他 動を，心魂とソーマそれぞれに固有の運動と見て いるのである，すなわちプラトンの場合，心魂の みが，自らによって内から自己自身や他のものを 動かすのであり，ソーマは，他のものによって外 から動かされる存在にすぎないのである注 17).

ただし，先に引用した箇所において（ $\mathrm{g} . \mathrm{X}$ $897 \mathrm{~A}-\mathrm{B})$ ，心魂の第一次的な運動がソーマの第 二次的な運動を導いていると言われていたよう に，プラトンは心魂とソーマを連関させ，ソーマ の運動に新たな様相を与えている。つまり，自動 の心魂は，他動のソーマを導くことで，それにあ る種の自律的な運動をもたらし ( L g.X 895C-D), さらには「知性」の助けを借りて，万物に斉一的 な現象を作り出しているのである ( $L g . X 897 \mathrm{C})$.

また，(1)の回転運動は，このような「知性」の 運動と同族的であるとされるが $(L g . X 897 D-$ 899B)，(2)の移動，すなわち「多くの場所におけ る運動」は, ソーマ同士の接触や衝突の起点とな るとともに，「無知」と同族的な運動となってい ると考えられる，というのもこの「無知」と同族
的な運動は，「同じ場所においてでもなければ， 同じ中心をめぐるのでもなく，同じものとの関係 においてでもなければ，一つの場所において動く のでもなく，秩序もなければ，規律もなく，また 何かの理法に従っているのでもない」(プラトン， 1976a，Lg. X 898B）と言われ，その背後には， あらゆるソーマの構成要素となる粒子（四元素） の渦動が想定されているからである.そしてこの 渦動こそが，ソーマの運動が無秩序であると言わ れる所以なのであって，(2)から(8)は，(2)を起点と して，一連の運動過程をなしつつ，9の他動に集 約されるのである住 ${ }^{18)}$.

このように，プラトンの場合，ソーマ同士の運 動変化はすべて, 充実空間における粒子の接触や 衝突によって引き起こされるのであり，(9)の他動 には，こうした粒子論的な運動過程を読み込む必 要があると言えよう。

ところで，『ティマイオス』でも，ソーマの運 動が，「他のものによって動かされて，また『必

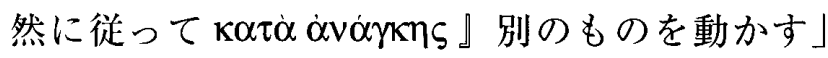
(プラトン，1975a，Ti. 46E）と言われ，他動が

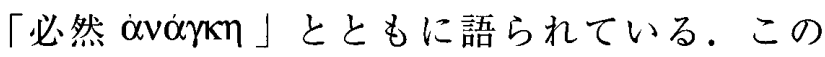
「必然」という言葉は，プラトンの著作において 論理学的な意味から運命や神の名前に至るまで 様々な使われ方をされているが注 19)，プロクロス （1967）によると，「『国家』のアナンケーの女神 が，神々を支配し……『ティマイオス』の必然は， ソーマの動力である」とされているのである。

また，『ティマイオス』に挙げられている七種 類の運動のうち（Ti. 34A）, 回転運動を除く，前 後左右上下の六つの連動は, 他動もしくは無秩序 な運動であり (Ti. 43B)，さらにこれらは多方向 的で，断続的であるがゆえに，渦動や休止の可能 性を持っていると考えられる $(T i .58 \mathrm{~A}-\mathrm{B})^{\text {i } 20)}$. つまり天体に見られる齐一的で円環的な運動に対 し，ソーマ同士の運動は無秩序で点線的なのであ って，『ティマイオス』の「必然」はこうした相 互依存的な運動の様相を表しているのである.

さらに，田中（1981，pp. 389-397）は，この ような「必然」を，アリストテレス（1959, p. 164, Metaph. 1015a20-21，1015a26）の観点 
から「条件的な必然」と「非合理的な必然」の二 つに区別している注21)。「条件的な必然」とは，あ る目的にとってはなくてはならない必要条件的な 必然性のことであり，他方「非合理的な必然」と は，目的論的な秩序から抜け落ちてしまう無理強 いの必然性のことである．たとえば，神々が人間 の頭を製作する場合 $(T i .75 \mathrm{~B}-\mathrm{C})$ ，人間の頭を 鋭敏なものにするために薄い骨を用いるならば, この薄い骨は，鋭敏な頭にとっては「条件的な必 然」となり得るだろう。しかし薄い骨の脆さに伴 って生じる災いは，頭にとって「非合理的な必然」 として立ち現れてくるのである注22).

また，Morrow（1950）は，上の分析を一歩進

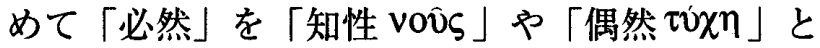
の関係から考察しており 注23)，「知性」と「偶然」 は「必然」によって生じる様々な「原因一結果」 の線を「配列 collocation」させる要因となってい ると指摘する。つまりかれによれば，「知性」は， 様々な因果の線を「集束 convergence」させてい くことで秩序をもたらし，他方「偶然」は一目的 に適うにせよ，適わないにせよ一「必然」の因果 的な連鎖を「交差 intersection」させ「結合 conjunction」させると言われているのである.

実際に『ティマイオス』のテクストにおいても，

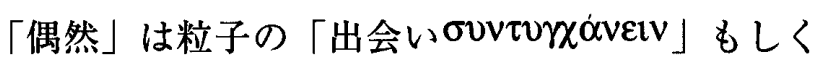

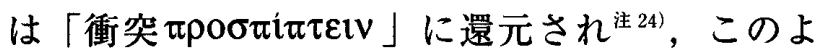
うな「偶然」の出会いが，後に続く「必然」の運 動契機となっていることがわかる $(T i .56 \mathrm{D})$ ）た だしすでに指摘したように，このような粒子の衝 突による運動は，あくまで無秩序であり，渦動や 休止の可能性を持っているのである.

また，『法律』第十巻において回転運動が「知 性」の運動と同族的であるとされていたように (Lg.X 897D-899B)，「ティマイオス』にも，「知 性」の秩序づけによって生じた円環的な運動が, 以下のように数多く見出される．たとえば「天体

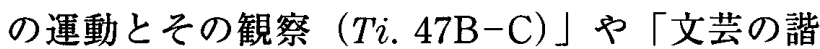
調 $(T i .47 \mathrm{C}-\mathrm{E})\rfloor,\lceil$ 呼吸の循環 $(T i .79 \mathrm{~B})\rfloor,\lceil キ ゙$ ユムナシアー（競技的運動）とその効果（Ti. $88 \mathrm{C}-89 \mathrm{~A}$ ) 」注 25) など，これら斉一的な現象はすべ て「知性」の回転運動と「必然」の点線的な運動
の協働によるものなのである ${ }^{\text {注 } 26)}$. このように，『ティマイオス』のテクストから も Morrow の指摘は十分に首肯され得るのであ $\eta ， 上 の 「$ 条件的な必然」と「非合理的な必然」 の差異は，様々な「原因一結果」の線を如何なる 契機によって「結合」していくかの違いにあるこ とがわかるだろう注27)。つまり，「必然」は「知性」 に支配され，善に方向づけられるならば，秩序の ある円環的な運動を行うが，無知や「偶然」にま かせて放置されるならば，行き当たりばったりで 無秩序な運動を行うことになるのである.

たしかに，ソーマは同じソーマとの関係におい ては，あくまで他から動かされ，渦動や休止の可 能性を持つ無秩序な運動を行うにすぎない．しか しながらプラトンの場合，ソーマは心魂や「知性」 と連関することで，一定の形態と方向性を持った 持続的な運動性を得ることになるのである。とく にプラトンは，天球や天体を生物とする独特の生 命観の持ち主であり，上で見たような運動の原理 は, マクロの天球からミクロの粒子まで一貫して いる．したがって，ソーマの運動性は，粒子の無 秩序な運動を構成要素としながらも，心魂や「知 性」に従う可能性を持った未完了的なプロセスと 言うべきものなのである.

\section{IV ソーマの感覚性}

プラトン（1976b，Sph. 248A）は，同じく後 期作品の『ソピステス』において，「われわれは ソーマにより，感覚を通じて，〈生成〉と関わり をもち，他方，心魂により，思惟を通じて，真の 〈実在〉と関わりをもつのだ」とエレアからの客 人に語らせているが，すでに中期作品の『パイド ン』でも，ソーマによる感覚の領域は，思惟によ る真実在の認識に比べ価值的にも低い位置づけを なされている（Phd.65A-66A，79A，79C， $83 \mathrm{~A}-\mathrm{C})$. ただしプラトンの場合，「アイステー シス (感覚一知覚)」の問題は, 認識論や感情論, 教育論など，幅広い分野にわたって論じられ，そ れに対するかれの捉え方も非常に多岐にわたって いる．本節では，それらすべてを把握することは 
不可能であるにしても，ある程度，アイステーシ スの成立過程とその役割を概観し，アイステーシ スがソーマ論にとってどのような意味を持つのか を問題にすることは可能だろう。

また，プラトン（1975b，Phlb. 34A）自身も 『ピレボス』の中で,「心魂とソーマとが一つパテ 一マ(情態変化) のなかに共同の形でおかれてい て，共同的にまた動くとき，この動を別にまた 『アイステーシス』という名で呼ぶ」と述べてい ることから，アイステーシスの考察には，心魂と ソーマの両面からのアプローチが必要であること がわかる注28).さらに『ティマイオス』では，ア イステーシスの成立過程が自然学的な観点から考 察されており，Brisson (1997, p. 162) は，その ようなプロセスを次のようにまとめている.

外からやって来る粒子が，人体のある部分にぶ つかり，もし，この衝突が，衝突する粒子の構 造や数, 速さに基づく, パテーマやパトスを引 き起こすならば，その時に発せられた運動は， 血液によって全身を通り，まずは，心魂の可死 的部分に，それから「プロニモン」と呼ばれる 理知的部分に伝達される。そこにおいて，その 運動は「アナムネーシス」と呼ばれるプロセス を誘発する。「アナムネーシス」とは，心魂が 身体から分離した時に観たイデアを想起するこ とであり, 想起は, 思考や名づけの活動が生ず るのを許すのである.

このようなBrissonの分析は, 非常に詳細で, かつ広範囲にわたっており，上の引用に収まりき らない部分もかなり存在するが，とりあえず，本 節では，上のプロセスを念頭におきながらソーマ の感覚性の考察を進めていくことにする．ただし Brissonが他の箇所で行っている感覚媒体や感覚 器官, 血液, 心魂の可死的部分 (すなわち, 不死 なる理知的部分に対する気概や欲望の部分）など の詳細な分析は, また別の機会に検討することに し，本節では，外的な刺激によって起こる熱冷乾 湿などの「パテーマやパトス（感覚的諸性質もし くは情態変化)」が，人体内の運動である「アイ
ステーシス (感覚一知覚)」となることで，人体 や心魂にどのような影響を与えるのか，を主に探 ってみることにしたい.

さて，すでに見た『法律』第十巻では，ソーマ の第二次的な運動として実体的な変化である増大 や減少，分離や結合のほかに，温かさや冷たさ， 重さや軽さ, 硬さや軟かさ, 白や黒, 苦さや甘さ などのパテーマ（感覚的諸性質）が挙げられてい たが，『ティマイオス』では，このようなパテー マは四元素（火水風土）の形態や運動に基づいて 説明されている，たとえば，熱さは，正四面体で ある火の粒子の微少さ, 棱線の繊細さ, 運動の速 さなどによって，それが接触するものを鋭く分断 させる結果であり，鈍さは，立方体である土の粒 子の大きさ，底面の坐りの良さ，運動の遅さによ るものなのである（Ti.56A-57A）.

また，上で見たように，ソーマ同士の運動変化 はすべて，充実空間における粒子の接触や衝突に よって引き起こされ，そのような接触によって生 まれるパテーマは，後に続く「必然」の運動契機 となっていたが，あくまでもこのような粒子の衝 突は「偶然」によるものなのであった（Ti.56D）。 そしてこのパテーマが粒子間の相互依存的な運動 によって引き起こされるには，粒子間の不等性に 基づく不均等性の維持が必要であり（Ti. 57E$58 \mathrm{C})$, さらに不等性はもともと個々の立体を構 成する要素三角形の大きさが，無限に多様である ことによって生じるとされているのである（Ti. $57 \mathrm{C}-\mathrm{D})$. つまり，パテーマとは，ある意味にお いて心魂とは関わりなく洋29), ソーマがソーマに よって蒙る情態変化を意味しており,さらにその 起源はそれぞれの粒子が持っている立体的構造の 異質性や多様性にあると考えられるのである。

ところで，このようなパテーマが人体に生じる 場合，それは人体にのみならず，心魂に如何なる 影響を及ぼすことになるのであろうか。たとえば 『ティマイオス』において神々が人体に心魂を結 びつけ，嬰児の動作が語られる場面では（Ti． 43B-44A)，パテーマが人体の無秩序な運動を引 き起こす原因として語られている．またパテーマ の影響が心魂にまで及ぶ場合には，その一連の運 
動がアイステーシスと呼ばれ，心魂の回転運動を 混乱させると言われているのである.しかもこの ような指摘は，他の箇所においてて体の健康が人 体の内外に生ずるパテーマによって脅かされ (Ti. 76E-A，88D)，さらにはそのような身体的 な条件によって心魂の病気も生ずる（Ti. $44 \mathrm{C}$ ， 86B-87A）と言われていることとも重なってく るだろう。つまりパテーマはソーマの領域に生じ て人体に様々な悪をもたらすだけでなく，その影 響が心魂に達してアイステーシスとなる場合，心 魂にも多くの悪をもたらすのである.

つまり, 先の運動性の分析では, 心魂の回転運 動だけでなく，人体の様々な領域にも斉一的な円 環運動が見られることを指摘したが，プラトンの 場合，人体においても心魂においても，外からや ってくる粒子の点線的な運動が, 斉一的な円環運 動を正常な運行から逸脱させたり，その回転の方 向を逆転させたりして，悪を生み出すのであ る ${ }^{\text {i土 }}{ }^{30)}$.『法律』第十巻の「多くの場所における運 動」が「無知」と同族的な運動と見られたように， 悪の起源は，粒子の形態の多様性，さらにはそれ によってもたらされる粒子の渦動にあると考えら れる望 31)。

これに対し，プラトンは『ティマイオス』の中 で，われわれ人間の視覚や聴覚が，天体の運行や 文芸の諧調に見られる斉一的な円環運動を受容 し，上のように混乱した心魂の回転運動を矯正す るために神々から与えられた（Ti. 47B-47E）と している，また，その『ティマイオス』では，パ テーマによって無秩序な運動を強いられている人 体に，「ギュムナシアー (競技的運動)」が万有や 思考と同族的な運動を作り出すと言われ（Ti. $88 \mathrm{C}-89 \mathrm{~A})$ ，さらに『法律』第二巻の教育論でも

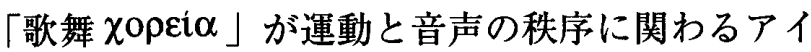
ステーシスを養うことが言われている（Lg. II 664E-665A)．つまりパテーマやアイステーシス は，人体や心魂のはたらきを混乱させる一方で, それらが斉一的な円環運動に従う場合には，様々 な秩序を回復するための手段ともなり得るのであ る.

というのも，『ティマイオス』では「必然的な
もの」としてのソーマは，「とにかくそれなくし ては，われわれが真剣に考える当の対象そのもの （すなわち「神的なもの」）も，それだけでは感知 することも，捉えることも，その他どんな仕方で でもそれに与ることができない」(プラトン， 1975a，Ti.69A）のであり，「神的なもの」とし ての善の追求に必要不可欠な手段となっているか らである。また上のような目的・手段関係は，以 下に挙げる『法律』の箇所からも傍証され得るの ではないだろうか. たとえば，すでに見た『法律』 第十巻において（ $L g . X 897 \mathrm{~A}-\mathrm{B} ）$ 心魂の第一次 的な運動がソーマの第二次的な運動を「利用する $\chi \rho \hat{\eta} \sigma \theta \alpha$ 」とされ，「なおその上に，『知性』の助 けをも得るなら……，万物を正しくまた幸福に導 くことになるし，他方，無知を仲間にした場合は， 万物をそれとは反対の状態にしてしまうわけで す」(プラトン，1976a，Lg. X 897B）と言われて いた.

さらに，『法律』の最終巻でも，国制と法律の 保全のために，どのようにして生物の安全がもた らされるのかが問題にされて，「知性」とアイス テーシスの関係が，次のように述べられている.

アテナイからの客人 心魂のなかには，他の能 力に加えて知性（ヌゥス）が宿っているし，ま た頭には，他の感覚に加えて視覚と聴覚とが具 わっている，ということによってなのです。そ して簡単にいえば，「知性」が，最も高貴な感 覚であるそれら二つの感覚と結びついて，これ らと一体となって㗢くときに，それぞれの生物 の安全は保たれるといって間違いないでしょ う.

クレイニアス それはたしかにそのようですね (プラトン, 1976a, Lg. XII 961D).

また，具体的な事例としては航海術や統帥術， 医術が挙げられ，それらの技術に関わる「知性」 はそれぞれ，船や軍隊，人体の安全のためにアイ ステーシスを結びつけると言われている。つまり 『ピレボス』でも強調されるように，もし快楽や アイステーシスが「知性」の支配に与らなければ, 
それらは生命体そのものの安全を勈かし，ひいて は快楽やアイステーシス自身の存在をも危うくす ることになるのである（Phlb，26B-C，61D， $62 \mathrm{E})$.

さらに，その『ピレボス』では，快楽の種類分 けの中で純粋快を伴うものとして「自体的に美な るもの」が紹介され，これは，「何かとの関係で 美しいというのではなくて，それ自体でいつも美 しくあるような本来自然のあり方をしていて，あ る種の快適さを自己自身のうちにもっている」 (プラトン，1975b，Phlb. 51E-D）と言われてい る。具体的には，形や直線，円，平面，立体など がそれであって，最終的に「知性」や思慮は，こ のような純粋快との混合を認め，さらには健康と 節制を伴う快楽やすべての徳（アレテー）に伴う 快楽もこの混合に加えているのである（Phlb. 63C-63A). とくに先に引用した『法律』第二巻 において，数や形，配置や秩序などが芸術判定の 基準におかれていたこと（Lg. II 668D-E）や， 『ティマイオス』で，パテーマが四元素の立体的 構造に即して説明されていたこと $(T i .56 \mathrm{~A}-57 \mathrm{~A})$ を併せて考えるならば，アイステーシスには，代 数学的あるいは幾何学的対象が先在していること がわかるだろう。

Brisson (1997, pp. 155-156) も，アイステー シスを生み出す運動の形態が, 感覚物と感覚器官 の代数学的対象の構造や数, 速さに依存し，アイ ステーシスの成立がそれら代数学的対象同士の 「尺度の一致 $\sigma v \mu \mu \varepsilon \tau \rho i ́ \alpha 」 に あ る と$ 見ている ${ }^{\text {ia }}{ }^{32}$. またBrisson（1997, pp. 159-163）は，心魂の欲 望的部分が思わくや計算や「知性」に決して与る ことがない $(T i .77 \mathrm{~B})$ と言われていることなど を典拠に，心魂の可死的部分（すなわち，気概や 欲望の部分）は，パテーマを知覚することはでき るが，パテーマについて思考したり，それらに名 前を与えることはできないとして，そのような能 力を心魂の理知的部分に求めているのである。い わば，この理知的部分こそがイデアの想起ととも に感覚印象に名前を与えるものであることは，本 節の初めに見たBrisson（1997，p. 162）の引用 にも示されていたとおりである.
実際に『パイドン』や『パイドロス』において も，アイステーシスは真実在 (イデア・エイドス) を思い浮かべる機縁となっており（Phd. 73C-E， 75A-B，75E-76A，76E, Phdr.249B-C), 総じ てパテーマやアイステーシスは, イデアの想起や, 知的もしくは言語的活動一般, 代数学的あるいは 幾何学的対象によって存在意義を与えられるもの であることがわかる。

とくに，『パイドン』では, 当時の唯物論的自 然学説の典型例とも言える「心魂ハルモニア一説」 に対し，心魂の身体に対する能動性に基づく反証 がなされている (Phd. 94B-D)。「心魂ハルモニ アー説」とは，非物体的な音楽の調べが物体的な 竪琴によって生成するが如く，心魂も身体的な諸 要素の調和（ハルモニアー）からなる可滅的な存 在であるとする説のことであり，現代の自然科学 的な生命論にも極めて近いと言える. しかし現実 には,ギュムナスティケーや医術の場合のように， 思慮ある（プロニモス）心魂は，単に身体のパテ ーマに同調し，受動的に従うのではなく，むしろ 諸々のパテーマに抵抗し，それらを能動的にコン トロールしているのであって，プラトンは，この 反証から「心魂ハルモニアー説」が抱える险路を 導き出すとともに，身体の心魂に対する従属性こ そが，そのような技術的アプローチを可能にする と考えているのである.

したがって，本節の始めにも述べたように，ソ 一マの感覚性は，粒子の多様性とその衝突によっ て引き起こされるパテーマ（情態変化もしくは偶 有的性質）にあると言えるが，一方で，パテーマ がアイステーシスとなって心魂や人体に無秩序な 運動をもたらすならば，それは悪の起源となるの であり，他方で，アイステーシスが心魂の「知性」 によって導かれるならば，それは秩序の回復やイ デアの想起の機縁ともなり得るのである。そして 後者のように「知性」とソーマの主従関係が保た れるとき，ソーマの感覚性もまた，空間性や運動 性と同じく，善や美の実現に必要不可欠な手段と なってくるのである. 


\section{おわりに}

これまで見てきたように，ソーマの原理的なあ り方を規定する, 空間性, 運動性, 感覚性といっ た三つの特性は，現代の自然科学的なそれらとは 異なるプラトン独自の様相を呈するものであっ た。まず，ソーマの空間性は，充実空間であるコ ーラーに投影されたイデアの似像であり，イデア の幾何学的形象化によって成立する立体性なので ある、また，ソーマの運動性は，もともと粒子の 「偶然」の衝突が「必然」に引き起こす無秩序で 点線的な他動性にあるが，ソーマが心魂や「知性」 と連関する場合には，自律的で斉一的な円環運動 を得ることになるのである，さらに，ソーマの感 覚性は，粒子の立体的構造の多様性に根拠を持つ パテーマ（情態変化もしくは偶有的性質）のこと であった. パテーマは，「無知」や「偶然」によ って放置される場合，心魂や人体に様々な悪をも たらすが，逆に「知性」の支配に与る場合には， 善の実現や秩序の回復に寄与することになるので ある。

したがって，これらの考察結果から言えること は, ソーマが, 従来のプラトン研究で指摘されて きたように，心魂や「知性」にとって否定的な存 在なのではなく，むしろ心魂や「知性」と不即不 離の関係におかれることで善悪いずれの方向にも 傾き, さらに, より積極的な意味においては, 善 の実現や秩序の回復に必要不可欠なものとなって いるということである注 33 . まさに，プラトンの 身体論を語りうる地平は, 心魂や「知性」, イデ アといった哲学原理によって切り拓かれるととも に，現代における無機質で，無目的で，没価值的 な物質の捉え方を相対化し，弁証法的に止揚して いく上でも，十分に有効性をそなえていると言え る.というのもそれらの哲学原理は，あらゆるソ 一マの成立原因となっており, 円環運動や幾何学 的対象, 言語活動などを通して, ソーマの形態や 運動に秩序や目的, 価值を与えているからである。 ただしこのような地平は，従来のように考察対象 を物体に限定せず，多種多様なソーマを分析して
いくことで，今後さらに拡張されるべきであるよ うに思われる。

そして，あらゆるソーマの存立が，心魂や「知 性」，イデアのはたらきによるのであれば，同じ くソーマと呼ばれる人間の身体も，「知性」のは たらきの一つであるギュムナスティケーとの関わ りに抒いて，自律的で秩序のあるものに改変され なければならない. おそらく，ギュムナスティケ 一が人間の身体に関わりうる根拠も，そのような ソーマの従属的かつ必要条件的なあり方に見出す ことができるのではないだろうか.

\section{謝 辞}

本稿の執筆にあたっては，佐藤臣彦先生（筑波 大学体育科学系）をはじめ, 本誌審査員の先生方 からも，様々なご教示をいただきました。記して 感謝いたします。

\section{注}

注 1) Cra. 400C, Grg. 493A, Phdr. 250C (Phd.62B). また，普通，古典ギリシア語の「プシューケ ー 坊」には，「たましい」という訳語が用い られているが，プラトンの言うプシューケーは， 精神の高度に意識的な側面から, 無意識的な生 命現象まで幅広い意味を持つものである，本研 究は, 田中（1981，pp. 87-88）に倣って，これ に「心魂」という訳語を当てることにした。な おギリシア・ローマの古典作品名の略記につい ては, L.S.J. (Liddle, Scott \& Jones, Greek English Lexicon) およびO.L.D. (Oxford Latin Dictionary）の略表記に従う.

注2）一般に, 古典ギリシア語の「ギュムナスティケ 一 という訳語が当てられているが, ギュムナステ イケーは，近代語の「体育」には収まりきらな い豊富な意味内容を持つ語である，とくに，プ ラトンの場合, このようなギュムナスティケー の外延の広さは，かれのギュムナスティケーに 関する思想内容にも少なからず影響しており， 訳出作業そのものは今後の研究成果を踏まえた 上で慎重に行われる必要があるだろう。これら の理由から, 本研究では, ギュムナスティケー 
を日本語に翻訳することはひとまず留保し，そ のまま片仮名で「ギュムナスティケー」と表記 することにした。

注3）近年，人間の身体を考察の対象とするものとし ては, Joubaud（1991）による『ティマイオス』 の注釈書が，またプラトンの身体論を再評価す るものとしては, Johansen（2000）による『テ イマイオス』の研究論文がすでに公にされてい る.

注4）著者（木庭，2001b）は，すでに別の機会にお いて, プラトン哲学の三原理である心魂や知性, イデアのそれぞれとソーマとの関係を考察する ことにより，自動と他動の主従関係，善と必然 の目的・手段関係，一と多の原範型一似像の関 係といった身体論の分析枠組みを提示している. プラトンの身体論は, かれの哲学思想のなかで 心魂論やイデア論の写しとして機能しているの であって，ギュムナスティケーの対象となる人 間の身体もまた，これらの分析枠組みを軸にし て再定義されるべきであることがすでに明らか にされている.

注 5)「ソーマ $\sigma \hat{\omega} \mu \alpha 」 の$ 外延が広いのは，アリスト テレスの場合も同様である.アリストテレスの 身体論については，桑子（1999）㧍よび佐藤 （1999）を参照されたい。

注 6) 底本には, Burnet（1900-1907），邦訳には， 田中・藤沢（1975-1978）の編集によるものを用 い,「ソーマ $\sigma \hat{\omega} \mu \alpha 」 の$ 訳語や細部の表現に関し て若干の変更を行った。

注 7) 同じく, 鈴木 (1982, pp. 227-274) や土屋 (1991）も，このような三つの観点からソーマに ついて論じている。ただし，鈴木の場合，運動 性から時間性を独立させて考察しているが，本 研究では, 時間性を運動性に含めて考察するこ とにする，時間性については，本文の第三節 「ソーマの運動性」および注26を参照されたい.

注 8）『ティマイオス』に揸いてケノン（空虚）の否 定が語られる箇所は，以下に示すとおりである. Ti. 58A, 59A, 79B-C, 80C.

注9）トポス（ところ）については，以下の箇所を参 照した.Ti.52A，57C，58B，60C，63C，63D， $72 \mathrm{~B}, 87 \mathrm{~A}$.

注 10）『ティマイオス』に抄いてディアケノン（間隙） の存在が語られる箇所は，以下に示すとおりで
ある。Ti.58B，59C，60E，61B，ただし59Cに は「間隙」の意味に ' $\delta i \alpha \lambda \varepsilon u \mu \mu \alpha$ 'いう語が使用 されている。この「空虚は認めないが，間隙は 認める」というプラトンの主張は，自らのうち に運動や停止の原理を持たない粒子（四元素） が，どのように活動を維持したり休止したりす るのかを説明するのに，必要不可欠な原則であ る。たとえば，本文でも述べたように，充害空 間において一つの空虚も残されていないとする と，充実している物の不可入性のために場所的 運動はあり得ず，さらには粒子の衝突によって 常に変化が引き起こされ，変化を伴わない場所 的運動はあり得ないことになってしまう。これ に対して，プラトンは，宇宙の内部に空虚の存 在を認めない代わりに，間隙の存在を認めて， 場所的運動の可能性を確保し，小さな粒子が大 きな粒子の間隙に移動して入り込む場合, 変化 は生じないと述べているのである（Ti. 58B）。こ の問題についてさらに詳しくは，本文の第三節 「ソーマの運動性」および注 17,18 を参照された い。またギリシア思想における空間概念につい ては，田中（1969）が詳しい解説を行っており， 筆者の見解も，この田中の論に依拠するところ が大きいと言える.

注11）ただし，ここで言う「質料la matière」とは, アリストテレスの言う意味での「形相」と相関 的な概念であり，広義では「素材」を意味する。 つまり，ブロシャール（Brochard）は，この語 の使用において，全く「形相」を持たないと言 われるアリストテレスの「第一質料」を念頭に おいているのであり, 同時にブロシャールの言 う「質料」はプラトン研究にあって「プラトン の物質 die platonische Materie, Platonic matter」 と言われているものであるだろう（Zeller，1889， SS. 721, S. 723 ; Cherniss, 1954, pp. 255). 鈴 木（1982，pp. 249-252）によれば，いわゆる 「プラトンの物質」は，その表現の不適切さにも かかわらず古くから用いられており, 感覚的物 体の根拠となるもの表しているとされる。また 金松（1976）が指摘しているように，プラトン 自身はコーラーを「質料」と呼んで㧍らず，コ ーラーはそこから世界が自然発生的に出て来た もとのものという意味での「質料」ではない. したがって「プラトンの物質」は，本研究の考 
察対象であるソーマと同じではなく，窮極的に はソーマの素材となるコーラーを意味している のである.

注 12）『ティマイオス』において「固有の場所」が語 られる箇所は，以下に示すと抢りである。Ti. 53A, 57C, 58B, 63B, 82A, 83A.

注 13)『ティマイオス』では, 天球 (Ti. 33B) や天体 (Ti. $40 \mathrm{~A})$, 人間の頭 (Ti. 33B) が「球形 $\sigma \phi \alpha 1 \rho 0 \varepsilon 1 \delta \varepsilon \varsigma 」$ に，頭の乗り物である胴体は「縦長 $\mu \eta \hat{K} \mathrm{Ko}\rfloor に に$ 作られている (Ti. 44E)，また脳は「どこから見 ても丸いもの $\pi \varepsilon \rho 1 \phi \varepsilon \rho \hat{\eta} \pi \alpha v \tau \alpha \chi \bar{\eta} 」$ とれ（Ti. $73 \mathrm{C}-\mathrm{D})$ ，さらに揈は「丸くて同時に長い形（円

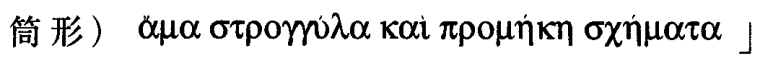
と言われている (Ti.73D). そして，これらの構 成要素となる四元素についても, 火が正四面体 に, 空気が正八面体に, 水が正二十面体に，土 が立方体に割り当てられて，それぞれが説明さ れているのである（Ti. 55D-56B）。

注 14）ディオゲネス＝ラエルティオス（1984, D.L. III 37）の証言によれば,『エピノミス』はオプ スのピリッポスという名の人物によるものとさ れているが，この証言を信頼する限り『エピノ ミス』はプラトン自身の作品ではないと言える のかもしれない.しかしながらキケロ（1999， De Or. III 6.21）の伝える『エピノミス」の引用 を証拠として，これをプラトンの真作と見る意 見も数多く存在する．またピリッポス自身も， プラトンの最晚年にアカデメイアで行われてい たプラトンの講義を聴講していたと考えられる ことから,『エピノミス』は, 真作, 偽作のいず れにしても，当時のアカデメイアでなされてい た学説を強く反映した作品であることに変わり はないだろう。

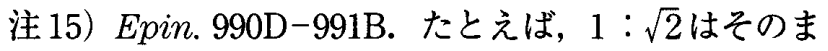
までは比較不可能であるが，それぞれと同じ長 さの比を一辺に持つ正方形を考えた場合, 両者 の面積は $1: 2$ となり, $\sqrt{2}$ は二倍の面積を持つ 正方形の一辺として理解可能なものとなる．ま たこのような無理数の発見は, アカデメイアの 最初からの一貝であったテアイテトスによるも のとされている（田中，1974）。ただしギリシア 人の幾何学では, ある種の大きさの積はたいて い別種の大きさとして表され，具体的な大きさ や量と切り離されてはいなかった（たとえば,
長さの積が, 平面や立体として表される).これ に対し，近世において，積をその一つ一つの因 数と同様に線分と考え, 次元の観念を一般化す る解析幾何学を完成させるのが, 近代哲学の祖, デカルト（1997, AT, VI, pp. 19-20) である. 注 16)このように, 代数学や幾何学の対象がイデア 界と現象界とを結ぶ媒介項となっていることは, Cornford（1932）やReale（1990）も強調すると ころである．またヴェドべリ（1975）が指摘し ているように, プラトンの代数学や幾何学の対 象は，単なる抽象観念ではなく感覚的で現実的 な存在をも含んでおり，このような感覚される 領域に属する代数学や幾何学の対象は, プラト ンのテクストにも数多く見出される。たとえば, 『国家』第六巻の「線分の比喻」(R. VI 510D-E) からも，思考される幾何学的対象と目に見える 幾何学的対象は, 原範型一似像の関係にあるこ とが読みとれるのであって，目に見える幾何学 的対象は, 思考される幾何学的対象のエイコー ン（似像）や補助手段となっていることがわか る.このように，目に見える幾何学的対象や代 数学的对象は, 概念的にはソーマから区別され ても存在的にはソーマと不可分であり，このこ とを示す用例は，プラトンのテクストにも数多 く見出すことができる（Men. 74A-76D, Cra. 432A, R. VII 525D, 530B, Phlb.56D-E, Epin. 991A).

注 17）このようなプラトンの考え方は, 自然によっ て存在するものはそれ自らのうちにそれの運動 および停止の原理〔始動因〕をもつ（Ph. 192b815）とするアリストテレス（1968a）の見解と鋭 い対照をなしている．またプラトンは，上のよ うな心魂動因説を，初期の『カルミデス』 (Chrm. 156E) から, 中期の『パイドロス』 (Phdr. 245C-246A), 後期の『ティマイオス』 （Ti. 34B-35A）を経て, 最晚年の『法律』まで 保持し続けている.

注 18）プラトンの場合, ソーマ同士の運動変化はす べて，充実空間における粒子の接触や衝突によ って引き起こされるのであり, 他動の解釈には, こうした粒子による一連の運動過程を念頭にお く必要があるだろう。詳細はVlastos（1975）や Taylor（1972，p. 293）の見解に依拠した筆者の 論文（木庭, 2001a）を参照されたい。 
注 19）「必然 $\alpha v \alpha \gamma k \eta 」$ 主な意味とそれらの使用さ れる箇所は，大体以下のようにまとめられるだ ろう.

(1)「必要やむをえない（善との対応で）」R．I 347C-O, II 358C, IV 493C，Phd.97Eなど.

(2)「自然学的な必然」Ti. $47 \mathrm{E}-48 \mathrm{~A}, 68 \mathrm{E}-69 \mathrm{~A}$, Lg. X 889B-C, XII 967A など.

(3)「論理学的な必然」Tht. 162E, Ti. 53D, 68B など.

(4)「必要なもの」R. II 369B-D, 373A-374E, Lg. VI 782D-783Aなど.

(5)「運命」Prt. 345D，Lg.V 741Aなど.

(6)「アナンケーの女神」R.X 616C，617B-D, 621Aなど.

なお「必然」の用例については『総索引」(岩波 プラトン全集別巻）を参照した（田中・藤沢， 1978).

注 20）同じく『パイドロス』(Phdr. 245C-246A）で も，ソーマの運動が休止の可能性を持つと言わ れている.

注21）ただし，田中の言う「合理性」とは，十八世 紀来の合理主義的な必然論を，目的論的秩序の うちに取り込んだ形での「統一的合理性」を意 味しているのであって，「非合理的な必然」とは， そのような目的論的秩序のうちにおさまりきら ない「無理強いの必然性」のことである。また Strange（1985）は，アリストテレスの『動物部 分論』(PA.642a8-14) を典拠に，「必然」を 「条件的必然」と「絶対的必然」に区別している。 アリストテレスの「必然」については，注 27） を参照されたい.

注22）またこのような「必然」は，本文に挙げた 「人間の頭の製作（Ti. 75B-C)」にもあるように， 一度ある目的が設定されれば，それ以外には一 挙両得を許さない単線的な運動であることがわ かる、たとえば，人体の場合でも，ある薬を処 方すると，同一の処方は，決まって人体のある 面には益になっても，別の面には明らかに害を 及ぼすことが言われたり（Lg.I 636A），優秀な 競技者が定められた生活法を少しでもふみはず すと，ひどい大病を患うことがあると言われた りしている (R. III 404A).

注23）『ティマイオス』の「必然」については，その ほかArcher-Hind（1988）やTaylor（1972, pp. 299-304), Cornford (1971) などもコメン トしているが，かれらの場合，ソーマや「補助 原因」，「迷動因」，「必然」，「偶然」などが，明 確に区別されておらず，それらの相互関係も十 分に把握されていない.

注 24）Vlastos（1939，p. 394）は，悪しき心魂や無秩 序な運動に関わるものとして「衝突 $\pi \rho 0 \sigma \pi \mathrm{i} \pi \tau \varepsilon l v\rfloor$ という語に着目している（Ti. 33A，43B，43C， $87 \mathrm{~A})$.

注 25）林・笛木（1994）は，プラトンの場合「ギュ ムナシアー 内容となる「鍛錬的運動」として理解され得る のであり，身体の善を作り出す技術としてのギ ユムナスティケーとは明確に区別される必要が あるとしている。また，アリストテレスもギュ ムナスティケーはギュムナシアーを媒介にして 身体の善を作り出すという認識に立っていたこ とが，すでに佐藤（1978）によって指摘されて いる.

注 26）同じくSkemp（1942）も，回転運動を四元素 に可能な運動とし，四元素が，コーラーの振動 による無秩序な直線運動とともに，知性の回転 運動にも従うことを指摘している。またVlastos （1939，pp. 383-385）は，時間の成立にも無秩 序な直線運動に対する斉一的な円環運動の支配 が認められるとしている。したがってソーマの 運動性と時間性は，パラレルに捉えることがで きると言えるだろう。

注27）もしくは，アリストテレス研究者に言わせれ ば，アスペクトの違いといったことになるだろ う。アリストテレスの「必然」については山田 （1989）と坂下（1992）の研究を参照した。とり わけ坂下（1992， p. 46）は，「一般的にいうと， 同一の素材・物質が同時に複数のアスペクトを 持つのであり，そのうちの或るアスペクトは構 成体の目的によって必要とされ，そのほかのア スペクトは不必要とされる」とした上で，同一 の物質に対して同時に「条件的必然性」と「絶 対的必然性」が所属しうると指摘している.

注 28）そのほか, 感覚の分析に心身両面からのアプ ローチが必要なことは『ティマイオス』にも示 唆されている $($ Ti. 43C，61C-D)，さらにアリス トテレス（1968b）も感覚の分析にあたってプラ トンと同じ方法に則っている (Sens. 436b1-8). 
注 29）ただし『ティマイオス』の記述から（Ti. 58A） 万有の心魂のはたらきは, 宇宙全体としての粒 子の渦動を維持するのに不可欠であることが読 みとれる，また『パイドン』の心魂不死の証明 においても, 万物の休止が生成の循環的構造に よって否定され，もし生成変化が反対のものへ 向かう直線的なものであれば, 万物は休止して しまうことが指摘されている $(P h d .72 \mathrm{~A}-\mathrm{B})$. すなわちこの『パイドン』の指摘は, 先の運動 性の考察でも見たように，心魂が直線的な生成 に対して向きを変え，再び元へ戻る運動を円環 的に作り出すということの裏づけにもなるので はないだろうか。

注 30）このような悪の捉え方は『ティマイオス』の 内部において一貫しており，人体の場合も，そ の諸々の構成要素が秩序から逸脱したり（Ti. 85C), 自然の理法に反した運動をしたりする (Ti. 83E) と, 様々な病気が生じるとされている. そのほかにも悪や病気が様々な循環運動の逆転 から生じるとされており，具体的には「嬰児の 心魂の描写 (Ti. 43A-44B)」や「二次的な組織 の病気 $(T i .82 \mathrm{C}-82 \mathrm{E}, 84 \mathrm{~A}-\mathrm{C}, 85 \mathrm{D})\rfloor$, 「心魂 の病気 $(T i .86 \mathrm{E}-87 \mathrm{~A}) 」$ 」どが挙げられる.

注 31）Vlastos（1939, p. 394）も粒子の衝突に悪の 原因を求める傾向にあり, かれは宇宙創造以前

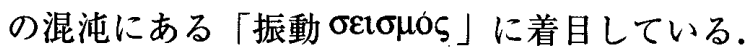
ただし宇宙創造以前の混沌はすでに「何らかの

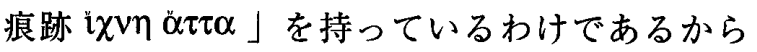
(Ti. 53B)，それだけで完全な悪と見なすことは できないだろう。さらに人間の身体の場合, 上 の振動は身体の世話にも利用されており, それ はコーラーのはたらきのように，「同族関係に従 って彷得っている身体の色々な諸情態や部分を， 相互に一定の配置へと秩序づけることで」身体 に健康をもたらすと言われているのである（プ ラトン, 1975a, Ti. 88D-88A).

注 32）Vlastos（1967）よれば，視覚や味覚における 「尺度の一致 $\sigma v \mu \mu \varepsilon \tau \rho i \alpha 」 は ，$ 粒子の大きさの 「比率 ratio」ではなく, 流体の密度の「一致 correspondence」に関わるとされている.

注 33）人間の身体が心魂やイデアとの連関からそれ 独自のあり方を呈するということは，筆者の別 の論文の中でも若干ふれられている（木庭， 2001b). 今後は, ソーマのより積極的なあり方
を，自然学や技術論，国家論といった具体的な 文脈なかで論じていくことにしたい.

\section{文献}

Archer-Hind, R.D. (1888) The Timaeus of Plato. Macmillan and Co: New York, pp. 162-163, p.167. アリストテレス：出 隆訳 (1959) 形而上学 (上). 岩波書店：東京.

アリストテレス：出 隆・岩崎允胤訳（1968a）自然 学（岩波アリストテレス全集 3 )。岩波書店：東京, pp. 44.

アリストテレス：副島民雄訳（1968b）感覚と感覚さ れるものについて. 自然学小論集（岩波アリスト テレス全集 6)。岩波書店：東京, p. 182.

Brisson, L. (1997) Plato's theory of sense perception in the Timaeus: How it works and what it means. In: Cleary, J.J. and Gurtler, G.M. (Eds.) (1999) Proceedings of the Boston Area Colloquium in Ancient Philosophy. XIII, Koninklijke Brill NV: Leiden.

ブロシャール：河野与一訳（1929）プラトン哲学に 於ける生成 哲学論丵 20 , 岩波書店：東京. 〈Brochard, V. et Dauriac, L. (1900) Le devenir dans la philosophie de Platon. In: Delbos, V. (1912) Étude de philosophie ancienne et de moderne. Vrin: Paris, pp. $95-112$.

Burnet, J. (Ed.) (1900-1907) Platonis opera (5 vols) . Oxford: London.

Cherniss, H.F. (1954) The sources of evil according to Plato. In: Proceedings of the American Philosophical Society 98: 23-30, repr. In: Tarán, L. (Ed.) (1977) Harold Cherniss selected papers. E. J. Brill: Leiden, pp. 253-260.

キケロ：大西英文訳（1999）弁論家について（キケ ロー選集 7). 岩波書店：東京, p. 342.

Cornford, F.M. (1932) Mathematics and dialectic in the Republic VI-VII. In: Allen, R.E. (Ed.) (1965) Studies in Plato's metaphysics. Routledge \& Kegan Paul: London, p. 63.

Cornford, F.M. (1971) Plato's cosmology. Routledge \& Kegan Paul: London, pp. 162-177.

デカルト：谷川多佳子訳（1997）方法序説. 岩波書 店：東京, pp. 30-31, p. 112 （第二部, 訳註 19）. 〈C. Adam et P. Tannery (Pb.) (1964-1974) Euvres 
de Descartes. J. Vrin: Paris.)

ディオゲネス＝ラエルティオス：加来彰俊訳（1984） ギリシア哲学者列伝（上）。岩波書店：東京, p. 277.

林 英彰・笛木 寛（1994）プラトンにおけるギュ ムナスティケーおよび同系派生語の用例分析。体 育原理研究 $25 ： 27-28$.

Jackson, H. (1882) Plato's later theory of Ideas. The Journal of Philology X (20): 253-298.

Johansen, T. (2000) Body, soul, and tripartition in Plato's Timaeus. In: Sedley, D. (Ed.) (2000) Oxford Studies in Ancient Philosophy. XIX, Oxford University Press: New York: 87-111.

Joubaud, C. (1991) Le corps humain dan la philosophie Platonicienne: Étude à partir du Timée. Vrin: Paris.

金松賢諒（1976）プラトンの神学と宇宙論。法蔵 館：京都, p. 116 .

木庭康樹（2001a）プラトン哲学における身体論一自 然学的考察を中心に一- 体育科学修士：筑波大学, pp. $50-52$.

木庭康樹（2001b）プラトン哲学における身体論序説 一体育哲学への方法論的アプローチ一．身体運動 文化研究 8 (1) : 1-15.

桑子敏雄（1999）解説. アリストテレス：桑子敏雄 訳（1999）心とは何か。講談社：東京, pp. 202205.

Morrow, G.R. (1950) Necessity and persuasion in Plato's Timaeus. In: Allen, R.E. (Ed.) (1965) Studies in Plato's metaphysics. Routledge \& Kegan Paul London, pp. $432-434$.

プラトン：種山恭子訳（1975a）ティマイオス（岩波 プラトン全集 12)，岩波書店：東京.

プラトン：森 進一ほか訳（1976a）法律（岩波プラ トン全集 13)。岩波書店：東京.

プラトン：田中美知太郎訳（1975b）ピレボス（岩波 プラトン全集 4)。岩波書店：東京.

プラトン：田中美知太郎訳（1976b）ソピステス（岩 波プラトン全集 3$)$ ．岩波書店：東京.

Proclus: Festugiére, A.J. (traduction et notes) (1967) Commentaire sur le Timée III. Librarie Philosohique J. Vrin: Paris, pp. 156-157.

坂下浩司（1992）アリストテレスの目的論における 物質の必然. 古代哲学研究 $24: 38-48$.
佐藤臣彦（1978）アリストテレスの体育技術論．新 体育 48 (4) : 318 .

佐藤臣彦（1999）身体論序説一アリストテレスを中 心に一。文学博士：筑波大学, p. 19.

Reale, G. (1990) A history of ancient philosophy. II. State University of New York Press: Albany, p. 112.

Rosen, S. (1995) Commentary on Sallis. In: Cleary, J.J. and Wians, W.C. (Eds.) (1997) Proceedings of the Boston Area Colloquium in Ancient Philosophy. XI, University Press of America: Boston: 175.

Sallis, J. (1995) Timaeus' discourse on the $\chi \omega \rho \alpha$. In: Cleary, J.J. and Wians, W.C. (Eds.) (1997) Proceedings of the Boston Area Colloquium in Ancient Philosophy. XI, University Press of America: Boston: 165

Sayre, K.M. (1998) The role of the Timaeus in the development of Plato's late ontology. Ancient Philosophy 18: 103-113.

シンプリキオス：内山勝利ほか訳（1997）アリスト テレス「自然学」注解.ディールス・クランツ： 内山勝利ほか訳（1997）ソクラテス以前の哲学者 断片集（第 II 分冊）。岩波書店：東京， p. 148. 〈Diels, H. und Kranz, W. (Hrsg.) (1984-1985) Die Fragmente der Vorsokratiker (2 vols, Wortindex) Weidmann: Germany.)

Skemp, J.B. (1942) The theory of motion in Plato's later dialogues. Cambridge University Press: Great Britain, p. 86.

Strange, S.K. (1985) The double explanation in the Timaeus. Ancient Philosophy 5: 412-413.

鈴木照雄（1982） ギリシア思想論放.二玄社：東京. 田中美知太郎（1969）空間と場所一ギリシア的思考 の一面一（田中美知太郎全集 5 巻). 筑摩書房：東 京, pp. 471-485.

田中美知太郎（1981）プラトン II 哲学（1）。岩波 書店：東京。

田中美知太郎（1974）『テアイテトス』解説（岩波プ ラトン全集 2)。岩波書店：東京, pp. 434-436.

田中美知太郎・藤沢令夫編（1975-1978）プラトン全 集（全 15 巻，別巻 1 ）。岩波書店：東京.

田中美知太郎・藤沢令夫編（1978）総索引（岩波プ ラトン全集別巻)。岩波書店：東京, pp. 431-435. Taylor, A.E. (1972) A commentary on Plato's 
Timaeus. Oxford: London.

土屋陸廣（1991）プラトンにおける悪と物体の問 題一『ティマイオス』の宇宙生成論をめぐって一. 倫理学年報 $40: 19-34$.

Vlastos, G. (1967) Plato's supposed theory of irregular atomic figures. In: Vlastos, G. (Ed.) (1973) Platonic studies. Princeton University Press: U.S.A, p. 372.

Vlastos, G. (1975) Plato's universe. University of Washington Press: Seattle, pp. 76-77.

Vlastos, G. (1939) The disorderly motion in the Timaeus. In: Allen, R.E. (Ed.) (1965) Studies in Plato's metaphysics. Routledge \& Kegan Paul: Lon- don, pp. 379-399.

ヴェドベリ：山川偉也訳（1975）プラトンの数理哲 学. 法律文化社, 京都, pp. 59-60. 〈Wedberg, A. (1955) Plato's philosophy of mathematics. Almqvist \& Wiksell: New York, p. 47.)

山田道夫（1989）アリストテレスに抢ける目的と必 然. 古代哲学研究 $21: 38-45$.

Zeller, E. (1889) Die Philosophie der Griechen in ihrer geschichtlichen Entwicklung. II. Vierte Auflage: Leipzig, SS. 721-723.

(平成 14 年 2 月 25 日受付 平成 15 年 3 月 27 日受理 